\title{
Pengaruh Gaya Kepemimpinan Transformasional Kepala Sekolah Terhadap Etos Kerja Guru dan Staf
}

\author{
Muhammad Luthfi Zharfan Fadhilah*, Suryadi, Abubakar \\ Universitas Pendidikan Indonesia, Bandung, Jawa Barat, Indonesia \\ Corresponding author: Muhammad Luthfi Zharfan Fadhilah \\ (e-mail: luthfizharfan1@student.upi.edu)
}

\begin{abstract}
Abstrak: Kepemimpinan transformasional berfokus pada pencapaian perubahan nilai-nilai, kepercayaan, sikap, perilaku, emosional, dan kebutuhan staf menuju perubahan yang lebih baik di masa depan. Penelitian ini bertujuan untuk mengetahui pengaruh gaya kepemimpinan transformasional kepala sekolah terhadap etos kerja guru dan staf. Sampel penelitian ini yaitu 56 guru dan staf di Sekolah Menengah Pertama Negeri 12 Bandung. Pengumpulan data dilakukan dengan kuesioner. Data yang terkumpul dianalisis secara kuantitatif menggunakan program Microsoft Excel 2016 dan SPSS 20for windows. Hasil penelitian menunjukkan bahwa ada hubungan yang signifikan antara gaya kepemimpinan transformasional kepala sekolah dan etos kerja guru beserta staf dengan nilai koefisien sebesar 0,370. Selain itu, gaya kepemimpinan transformasional kepala sekolah berpengaruh sebesar $13,7 \%$ terhadap etos kerja guru dan staf. Jika gaya kepemimpinan transformasional kepala sekolah ditingkatkan sebesar 53,483 maka nilai etos kerja guru dan staf akan bertambah sebesar 0,260. Berdasarkan hasil penelitian tersebut, penelitian ini merekomendasikan perlunya pengembangan dan penerapan kepemimpinan transformasional kepala sekolah.
\end{abstract}

Kata Kunci : kepemimpinan transformasional, kepemimpinan kepala sekolah, etos kerja

\section{The Influence of Principal's Transformational Leadership Style on the Work Ethic of Teachers and Staff}

\begin{abstract}
Transformational leadership focuses on achieving changes in the values, beliefs, attitudes, behaviors, emotional, and needs of staff towards a better change in the future. This study aims to determine the effect of the principal's transformational leadership style on the work ethic of teachers and staff. The sample of this research is 56 teachers and staff at 12 Bandung State Junior High School. Data collection was carried out by means of a questionnaire. The collected data were analyzed quantitatively using Microsoft Excel 2016 and SPSS 20 for windows. The results showed that there was a significant relationship between the transformational leadership style of the principal and the work ethic of teachers and staff with a coefficient value of 0.370. In addition, the principal's transformational leadership style has an effect of $13.7 \%$ on the work ethic of teachers and staff. If the principal's transformational leadership style is increased by 53.483, the value of the work ethic of teachers and staff will increase by 0.260. Based on these results, this study recommends the need for the development and application of principal transformational leadership.
\end{abstract}


Keywords: transformational leadership, principal leadership, work ethic

\section{PENDAHULUAN}

Salah satu yang menjadi tolak ukur keberhasilan sekolah adalah etos kerja guru dan staf. Hal tersebut didapatkan dari hasil etos kerja yang optimal. Prosesnya dimulai dari merencanakan, melaksanakan, dan mengevaluasi kegiatan belajar mengajar yang dilandasi oleh etos kerja serta disiplin profesional guru. Kegiatan tersebut dilakukan oleh guru maupun tenaga kependidikan dalam menyiapkan faktor-faktor yang berpengaruh secara langsung maupun tidak langsung terhadap keberlanjutan kegiatan belajar mengajar. Etos kerja guru dan staf tersebut tentu akan berpengaruh terhadap keberhasilan sekolah karena mempunyai tugas dan fungsinya masingmasing.

Kepemimpinan transformasional merupakan pemimpin yang kharismatik dan mempunyai peran sentral serta strategis dalam membawa organisasi mencapai tujuannya. Pemimpin transformasional juga harus mempunyai kemampuan untuk menyamakan visi masa depan dengan bawahannya, serta mengakomodir kebutuhan bawahan pada tingkat yang lebih tinggi dari pada apa yang mereka butuhkan. Menurut Danim (2004) kepemimpinan transformasional adalah kemampuan seseorang pemimpin dalam bekerja dengan dan/atau melalui orang lain untuk mentransformasikan, secara optimal sumber daya organisasi dalam rangka mencapai tujuan yang bermakna sesuai dengan target capaian yang telah ditetapkan. Menurut Bass dalam Yukl (2010), kepemimpinan transformasional adalah suatu keadaan dimana para pengikut dari seorang pemimpin transformasional merasa adanya kepercayaan, kekaguman, kesetiaan, dan hormat terhadap pemimpin tersebut, dan mereka termotivasi untuk melakukan lebih dari harapan pemimpinnya.

Selanjutnya, Burns dalam Safaria (2004) menjelaskan kepemimpinan transformasional dicirikan sebagai pemimpin yang berfokus pada pencapaian perubahan nilai-nilai, kepercayaan, sikap, perilaku, emosional, dan kebutuhan bawahan menuju perubahan yang lebih baik di masa depan. Kepemimpinan ini digunakan oleh seorang manajer bila ingin suatu kelompok melebarkan batas dan memiliki kinerja melebihi status quo organisasi mencapai serangkaian sasaran organisasi yang sepenuhnya baru (O’Leary dalam Pradana \& Bambang, 2013). Mendukung pandangan tersebut, Robbins (2008) mengatakan bahwa pemimpin transformasional adalah pemimpin yang menginspirasi para pengikutnya untuk menyampingkan kepentingan pribadi mereka demi kebaikan organisasi dan mampu memiliki pengaruh yang luar biasa pada diri para pengikutnya.. 


\subsection{Ciri-ciri kepemimpinan transformasional}

Menurut Robbins (2008), ciri-ciri kepemimpinan transformasional, meliputi idealized influence (pengaruh ideal); adalah perilaku pemimpin yang memberikan visi dan misi, memunculkan rasa bangga, serta mendapatkan respek dan kepercayaan bawahan. Idealized influence disebut juga sebagai pemimpin yang kharismatik, dimana pengikut memiliki keyakinan yang mendalam pada pemimpinnya, merasa bangga bisa bekerja dengan pemimpinnya, dan memercayai kapasitas pemimpinnya dalam mengatasi setiap permasalahan.

Inspirational motivation (motivasi inspirasional); adalah perilaku pemimpin yang mampu mengkomunikasikan harapan yang tinggi, menyampaikan visi bersama secara menarik dengan menggunakan simbol-simbol untuk memfokuskan upaya bawahan dan mengispirasi bawahan untuk mencapai tujuan yang menghasilkan kemajuan penting bagi organisasi. Intellectual stimulation (stimulasi intelektual); adalah perilaku pemimpin yang mampu meningkatkan kecerdasan bawahan untuk meningkatkan kreativitas dan inovasi mereka, meningkatkan rasionalitas, dan pemecahan masalah secara cermat. Individualized consideration (pertimbangan individual); adalah perilaku pemimpin yang memberikan perhatian pribadi, memperlakukan masing-masing bawahan secara individual sebagai seorang individu dengan kebutuhan, kemampuan, dan aspirasi yang berbeda, serta melatih dan memberikan saran.

Individualized consideration dari kepemimpinan transformasional memperlakukan masing-masing bawahan sebagai individu serta mendampingi mereka, memonitor dan menumbuhkan peluang. Luthans dalam (Safaria, 2004), pemimpin transformasional memiliki beberapa karakteristik tertentu, yaitu: pemimpin mengidentifikasikan dirinya sendiri sebagai agen perubahan, pemimpin mendorong keberanian dan pengambilan resiko. pemimpin percaya pada orang-orang, pemimpin dilandasi oleh nilai-nilai, pemimpin adalah seorang pembelajar sepanjang hidup (lifelongs learners), pemimpin memiliki kemampuan untuk mengatasi kompleksitas, ambiguitas, dan ketidakpastian dan pemimpin juga adalah seorang yang visioner.

\subsection{Prinsip-prinsip kepemimpinan transformasional}

Prinsip-prinsip yang harus diciptakan oleh seorang pemimpin transformasional menurut (Rees, 2001) adalah simplifikasi. Simplikasi merupakan keberhasilan dari pemimpin untuk menyederhanakan dengan sebuah visi yang akan menjadi cermin dan tujuan bersama. Kemampuan serta keterampilan dalam mengungkapkan visi secara jelas, praktis dan tentu saja 
transformasional yang dapat menjawab tantangan organisasi tentu menjadi hal pertama yang penting untuk diimplementasikan.

Prinsip selanjutnya adalah motivasi yaitu kemampuan untuk mendapatkan komitmen dari setiap orang yang terlibat terhadap visi yang sudah dijelaskan. Pada saat pemimpin transformasional dapat menciptakan suatu sinergitas di dalam organisasi, berarti seharusnya dia dapat pula mengoptimalkan, memotivasi dan memberi energi kepada setiap pengikutnya. Praktisnya dapat saja berupa tugas atau pekerjaan yang betul-betul menantang serta memberikan peluang bagi mereka pula untuk terlibat dalam suatu proses kreatif baik dalam hal memberikan usulan atau pun mengambil keputusan dalam pemecahan masalah, sehingga hal ini pula akan memberikan nilai tambah bagi mereka sendiri.

Fasilitasi merupakan prinsip selanjutnya yang berarti kemampuan untuk secara efektif memfasilitasi pembelajaran yang terjadi di dalam organisasi secara kelembagaan, kelompok, ataupun individual. Hal ini akan berdampak pada semakin bertambahnya modal intelektual dari setiap orang yang terlibat di dalamnya. Prinsip selanjutnya adalah mobilitasi, yaitu pengerahan semua sumber daya yang ada untuk melengkapi dan memperkuat setiap orang yang terlibat di dalamnya dalam mencapai visi dan tujuan. Pemimpin transformasional akan selalu mengupayakan pengikut yang penuh dengan tanggung jawab.

Prinsip berikutnya yakni siap siaga yang merupakan kemampuan untuk selalu siap belajar tentang diri mereka sendiri dan menyambut perubahan dengan paradigma baru yang positif. Tekad merupakan prinsip lainnya dari sosok pemimpin yang transformasional, yaitu tekad bulat untuk selalu sampai pada akhir, tekad bulat untuk menyelesaikan sesuatu dengan baik dan tuntas. Tentu perlu pula didukung oleh pengembangan disiplin spiritualitas, emosi, dan fisik serta komitmen. Pemimpin transformasional adalah orang yang membantu perusahaan dan orang lain untuk membuat perubahan positif dalam aktivitas mereka. Perubahan itu sering kali berskala besar dan dramatis.

Setelah menetapkan arah baru yang menarik bagi perusahaan atau menciptakan masa depan, pemimpin biasanya memilih salah satu dari enam metode yang ada untuk melahirkan perubahan. Tindakan paling luas yang dilakukan pemimpin transformasional adalah mengubah kultur organisasi (Dubrin, 2005). Ini berarti bahwa nilai, sikap, dan bahkan atmosfer organisasi memungkinkan untuk berubah. Perubahan paling umum adalah mengubah kultur dari kultur birokratis, kaku dan sedikit mengambil resiko menjadi kultur di mana orang bisa lebih bergerak dan tidak terlalu dibatasi oleh aturan dan regulasi. Selanjutnya adalah meningkatkan kesadaran orang tentang imbalan, pemimpin transformasional membuat anggota kelompok sadar akan arti penting imbalan tertentu dan bagaimana cara mendapatkannya. Pemimpin mungkin dapat 
menyebutkan kebanggaan yang akan dirasakan karyawan jika perusahaan menjadi nomor satu dibidangnya.

Prinsip selanjutnya adalah membantu orang tidak sekedar mengejar kepentingan diri. Pemimpin transformasional membantu anggota kelompok untuk melihat pada gambaran yang lebih besar demi kebaikan tim dan organisasi. Sedikit demi sedikit pemimpin membuat pekerja menyadari bahwa tindakan mereka memberi kontribusi pada tujuan yang lebih luas ketimbang sekedar memenuhi kepentingan diri sendiri. Membantu orang mencari pemenuhan diri juga menjadi prinsip seorang pimpinan yang transformasional. Pemimpin transformasional membantu orang lain untuk tidak sekedar berfokus pada kesuksesan kecil-kecilan, tetapi juga pada usaha mencari pemenuhan diri. Memberi pemahaman kepada orang lain tentang keadaan urgen tentu bagian dari prinsip organisasi. Guna menciptakan transformasi, pemimpin mengumpulkan para manajer kritis dan karyawan lainnya dan melibatkan mereka dalam diskusi urgensi perubahan. Prinsip terakhir adalah mengejar kejayaan. Tindakan transformasional tertinggi adalah membuat orang lain bersemangat untuk melakukan kerja keras demi kebesaran dan kejayaan organisasi.

\subsection{Kepemimpinan kepala sekolah}

Kepala sekolah sebagai pemimpin adalah orang yang mempunyai kemampuan mempengaruhi guru dan staf untuk melakukan pekerjaannya sesuai dengan tujuan yang hendak dicapai. Pencapaian tujuan tersebut dapat dilihat dari peningkatan kinerja guru. Kepemimpinan kepala sekolah dapat dilakukan dengan menerapkan fungsi-fungsi manajemen dalam merencanakan, mengorganisir, dan mengevaluasi visi, misi, dan tujuan sekolah yang sudah ditetapkan secara bersama. Kinerja guru merupakan kualitas dan kuantitas yang dicapai dalam melaksanakan tugasnya sebagai pendidik dan pengajar secara bertanggung jawab. Kinerja merupakan penyelesaian tugas-tugas yang dilimpahkan kepala sekolah kepada guru. Tugas guru dapat dibedakan menjadi dua yaitu bidang akademik yang berkaitan dengan proses pembelajaran dan administrasi. Keberhasilan kepemimpinan kepala sekolah dalam memimpin sekolahnya ditunjukkan oleh meningkatnya kesadaran para guru untuk meningkatkan kinerjanya sebagai salah satu faktor dari etos kerja, meningkatnya keterampilanan guru dalam melaksanakan, tugas pembelajaran, meningkatnya prestasi guru secara professional, dan meningkatnya prestasi belajar peserta didiknya.

Pengertian kepala sekolah menurut Wahjosumidjo (2002) dapat diartikan 'Ketua' atau 'pemimpin' dalam suatu organisasi atau sebuah lembaga. Lebih lanjut, sekolah diartikan 
sebagai sebuah lembaga dimana menjadi tempat menerima dan memberi pelajaran. Dengan demikian secara sederhana kepala sekolah dapat didefinisikan sebagai seorang tenaga fungsional guru yang diberi tugas untuk memimpin suatu sekolah dimana diselenggarakan proses belajar mengajar, atau tempat dimana terjadi interaksi antara guru dengan murid. Daryanto (2005) mendefinisikan kepala sekolah merupakan orang yang bertanggung jawab terhadap seluruh kegiatan-kegiatan sekolah. Kepala sekolah mempunyai wewenang dan tanggung jawab penuh untuk menyelenggarakan seluruh kegiatan pendidikan dalam lingkungan sekolah yang dipimpinnya.

Kepala sekolah tidak hanya bertanggung jawab secara teknis akademis saja, akan tetapi segala kegiatan. Termasuk keadaan lingkungan sekolah dengan masyarakat sekitar. Kepemimpinan yang berorientasi kepuasan personal seringkali disukai bawahan. Untuk itu diperlukan kepala sekolah yang memiliki pengetahuan kepemimpinan baik perencanaan, pengorganisasian, pelaksanaan, dan pengawasan suatu program sekolah dan pendidikan secara luas. Selain itu, kepala sekolah harus menunjukkan semangat bekerja tinggi, disiplin, keteladanan dan hubungan kemanusiaan dalam rangka perwujudan iklim kerja yang baik dan kondusif. Prinsip kebersamaan, bekerja dengan tim sangat diperlukan sehingga akan tercapai tujuan sekolah secara produktif sesuai dengan ketentuan yang telah ditetapkan.

\subsection{Konsep etos kerja}

Etos berasal dari bahasa Yunani (ethos) yang memberikan arti sikap, kepribadian, watak, karakter, serta keyakinan atas sesuatu. Sikap ini tidak saja dimiliki oleh individu, tetapi juga oleh kelompok bahkan masyarakat. Etos dibentuk oleh berbagai kebiasaan, pengaruh budaya, serta sistem nilai yang diyakininya. Dari kata etos ini, dikenal pula kata etika, etiket yang hampir mendekati pada pengertian akhlak atau nilai-nilai yang berkaitan dengan baik buruk (moral), sehingga dalam etos tersebut terkandung gairah atau semangat yang amat kuat untuk menyempurnakan sesuatu secara optimal, lebih baik, dan bahkan berupaya untuk mencapai kualitas kerja yang sesempurna mungkin.

Etos adalah sifat, karakter, kualitas hidup, moral dan gaya estetika serta suasana hati seseorang masyarakat. Kemudian mengatakan bahwa etos berada pada lingkaran etika dan logika yang bertumpuk pada nilai-nilai dalam hubungannya pola-pola tingkah laku dan rencana-rencana manusia. Etos memberi warna dan penilaian terhadap alternatif pilihan kerja, apakah suatu pekerjaan itu dianggap baik, mulia, terpandang, salah dan tidak dibanggakan. Etos kerja merupakan dasar motivasi yang terdapat dalam budaya suatu masyarakat, yang 
menjadi penggerak batin anggota masyarakat pendukung budaya untuk melakukan suatu kerja. Etos kerja juga merupakan nilai-nilai tertinggi dalam gagasan budaya masyarakat terhadap kerja yang menjadi penggerak bathin masyarakat melakukan kerja, pandangan hidup yang khas dari sesuatu masyarakat terhadap kerja yang dapat mendorong keinginan untuk melakukan pekerjaan.

Sinamo (2005) menyebutkan lebih memilih menggunakan istilah etos karena menemukan bahwa kata etos mengandung pengertian tidak saja sebagai perilaku khas dari sebuah organisasi atau komunitas tetapi juga mencakup motivasi yang menggerakkan mereka, karakteristik utama, spirit dasar, pikiran dasar, kode etik, kode moral, kode perilaku, sikapsikap, aspirasi-aspirasi, keyakinan-keyakinan, prinsip-prinsip, dan standar-standar. Menurut Anoraga (1992) etos kerja merupakan suatu pandangan dan sikap suatu bangsa atau umat terhadap kerja. Bila individu-individu dalam komunitas memandang kerja sebagai suatu hal yang luhur bagi eksistensi manusia, maka etos kerjanya akan cenderung tinggi. Sebaliknya sikap dan pandangan terhadap kerja sebagai sesuatu yang bernilai rendah bagi kehidupan, maka etos kerja dengan sendirinya akan rendah.

Pendapat Sinamo (2005) tentang etos kerja adalah seperangkat perilaku positif yang berakar pada keyakinan fundamental yang disertai komitmen total pada paradigma kerja yang integral. Menurutnya, jika seseorang, suatu organisasi, atau suatu komunitas menganut paradigma kerja, mempercayai, dan berkomitmen pada paradigma kerja tersebut, semua itu akan melahirkan sikap dan perilaku kerja mereka yang khas. Itulah yang akan menjadi etos kerja dan budaya. Selain itu, Sinamo (2005) juga memandang bahwa etos kerja merupakan fondasi dari sukses yang sejati dan otentik. Pandangan ini dipengaruhi oleh kajiannya terhadap studi-studi sosiologi sejak zaman Max Weber di awal abad ke-20 dan penulisan - penulisan manajemen dua puluh tahun belakangan ini yang semuanya bermuara pada satu kesimpulan utama; bahwa keberhasilan di berbagai wilayah kehidupan ditentukan oleh perilaku manusia, terutama perilaku kerja. Sebagian orang menyebut perilaku kerja ini sebagai motivasi, kebiasaan (habit) dan budaya kerja. Menurut Soetopo (2010) keyakinan dan asumsi merupakan bagian dari budaya kerja dalam organisasi. Oleh sebab itu dapat disimpulkan bahwa budaya organisasi dapat mempengaruhi keefektifan organisasi.

Apabila dikaitkan dalam bidang pendidikan maka suatu organisasi dapat merupakan sebuah sekolah. Keberhasilan sekolah sebagai bentuk organisasi dapat diukur dari tingkat kinerja guru dan staf. Ada juga faktor yang mempengaruhi kinerja dari guru dan staf tersebut yaitu kepemimpinan dari seorang kepala sekolah yang memegang peran yang sangat penting, karena menyangkut berhasil tidaknya kegiatan pendidikan di sebuah lembaga pendidikan 
tersebut. Begitu pula kepemimpinan kepala sekolah di Sekolah Menengah Pertama Negeri 12 Bandung yang menjadi lokasi kajian ini. Sekolah ini memiliki kepala sekolah yang mempunyai kemampuan tinggi dalam menjalankan berbagai aktivitas pendidikan yang ada di sekolah, mulai dari perencanaan, pelaksanaan, evaluasi serta program tindak lanjut. Kepala sekolah SMP Negeri 12 ini menyamakan visi bersama dan mengoptimalkan sumber daya sehingga dapat megubah masa depan menjadi lebih baik atau dengan kata lain "transformasional".

Berdasarkan pra-survei yang dilakukan, kepala sekolah SMP 12 Negeri Bandung telah bisa menjalankan tugasnya sesuai dengan tupoksi beliau menjadi kepala sekolah. Beberapa hal yang masih kurang adalah terkait hubungan antara kepala sekolah, guru dan staf dalam etos kerja. Aktivitas guru dan staf dalam melaksanakan tugasnya masih dipengaruhi oleh kepemimpinan kepala sekolah. Kepemimpinan seorang kepala sekolah berdampak sangat besar dalam meningkatkan kinerja guru yang memunculkan etos kerja dari guru dan staf seperti semangat dalam mengerjakan tugasnya masing-masing, berdedikasi tinggi terhadap sekolah, menjunjung tinggi kebersamaan dalam bekerja dan sama sama mencapai tujuan sekolah. Sehingga berdasarkan penjelasan di atas, maka penting bagi peneliti untuk mengkaji lebih dalam terkait pengaruh gaya kepemimpina transformasional terhadap etos kerja guru dan staf di SMP Negeri 2 Bandung.

\section{METODE PENELITIAN}

Penelitian ini menggunakan pendekatan kuantitatif sebagai metode penelitian yang berlandaskan pada filsafat positivisme. Sumber data pada penelitian ini adalah guru dan tenaga administrasi sekolah (tendik) sejumlah 28 orang. Pengumpulan data menggunakan instrumen penelitian dalam bentuk kuesioner. Penyebaran angket dilakukan dengan menggunakan google form yang disebarkan pada grup WhatsApp sekolah. Teknik analisis data menggunakan statistik dengan tujuan untuk menguji hipotesis yang telah ditetapkan. Uji keabsahan data korelasi meliputi uji normalitas dan uji linearitas. Uji normalitas dilakukan dengan aplikasi SPSS Versi 20 for windows dengan rumus One-Sample Kolmogorov-Smirnov Test. Adapun hipotesis dasar pengambilan keputusan uji normalitas yang digunakan oleh peniliti adalah dengan melihat Asymptotic significance 2-tailed pada tabel hasil uji normalitas dengan bantuan aplikasi program SPSS versi 20 for windows sebagai berikut: Ho: tidak terdapat perbedaan antara distribusi data dengan normal (berdistribusi normal); Ha: terdapat perbedaan antara distribusi data dengan distribusi normal (berdistribusi tidak normal).

Dasar pengambilan keputusan dengan ketentuan sebagai berikut: 1) Nilai asympotic significance 2-tailed > 0,05, maka Ho diterima berarti tidak terdapat perbedaan antara distribusi 
data dengan distribusi normal; 2) Nilai asymptotic significance 2-tailed $<0,05$, maka $\mathrm{Ha}$ diterima berarti tidak terdapat perbedaan antara distribusi data dengan distribusi normal. Adapun hasil uji normalitas masing-masing variabel dengan menggunakan SPSS versi 20 for windows sebagai berikut:

Tabel 1. One-Sample Kolmogorov-Smirnov Test

\begin{tabular}{llrr}
\hline & & X & \multicolumn{1}{c}{ Y } \\
\hline $\mathrm{N}$ & & 56 & 56 \\
Normal Parameters & Mean & 80.48 & 88.30 \\
& Std. Deviation & 13.884 & 8.889 \\
& Absolute & .171 & .136 \\
Most Extreme Differences & Positive & .078 & .136 \\
& Negative & -.171 & -.075 \\
Kolmogorov-Smirnov Z & & 1.283 & 1.017 \\
Asymp. Sig. (2-tailed) & & .074 & .252 \\
\hline a. Test distribution is Normal. & & & \\
b. Calculated from data. & & &
\end{tabular}

Uji linearitas dilakukan untuk mengetahui apakah terdapat hubungan yang linier antara kedua variabel penelitian. Hubungan yang linier menggambarkan bahwa perubahan pada variabel akan membentuk garis linier. Adapun kedua variabel berhubungan secara linier atau tidak yaitu sebagai berikut: 1) Jika Skor $\mathrm{P}<0,05$ maka kedua variabel dinyatakan linier; 2) Jika Skor P > 0,05 maka kedua variabel dinyatakan tidak linier. Penghitungan uji linearitas hubungan dalam penelitian ini menggunakan bantuan program SPSS versi 20 for windows. Pada tabel anova terdapat nilai signifikansi yang dimana jika > 0,05 maka terdapat hubungan yang linear diantara kedua variabel sedangkan jika $<0,05$ maka tidak terdapat hubungan yang linear diantara kedua variabel tersebut. Hasil uji linearitas menunjukkan bahwa hubungan kedua variabel adalah sudah linier, sehingga dengan terpenuhinya kedua asumsi tersebut (normalitas dan linearitas), maka analisis data dapat diteruskan dengan uji hipotesis melalui teknik Analisis Product Moment.

\subsection{Pengujian hipotesis penelitian}

\subsubsection{Analisis koefisien korelasi}

Suharsimi Arikunto menjelaskan bahwa koefisien korelasi adalah suatu alat statistik, yang dapat digunakan untuk membandingkan hasil pengukuran dua variabel yang berbeda agar dapat menentukan tingkat hubungan antara variabel-variabel ini (Arikunto, 2006). Adapun rumus korelasi product-moment (rumus 3) yang digunakan peneliti adalah sebagai berikut :

$$
r=\frac{\sum x y-\left(\sum x\right)\left(\sum y\right)^{2}}{\sqrt{\left(n \sum x\right)-\left(\sum x\right)^{2}\left(n \sum y\right)-\left(\sum y\right)^{2}}}
$$


Keterangan:

$r \quad$ : Korelasi antara kepemimpinan transformasional kepala sekolah dengan etos kerja guru dan staf

$x \quad$ : Variabel kepemimpinan transformasional kepala sekolah

y : Variabel etos kerja guru dan staf

xy : Jumlah skor hasil perkalian skor X dan Y

n : Jumlah sampel yang diteliti

Dengan internal koefisien: $0 \leq \mathrm{r} \geq 1$, menafsirkan besarnya koefisien korelasi dengan klasifikasi diperoleh dari (Sugiyono, 2013) sebagai berikut:

Tabel 2. Kriteria Harga Koefisien Korelasi

\begin{tabular}{ll}
\hline Interval Koefisien & Tingkat Hubungan \\
\hline $0,80-1,000$ & Sangat Kuat \\
$0,60-0,799$ & Kuat \\
$0,40-0,599$ & Cukup Kuat \\
$0,20-0,399$ & Rendah \\
$0,00-0,199$ & Sangat Rendah \\
\hline
\end{tabular}

\subsubsection{Uji signifikansi koefisien korelasi}

Pengujian signifikansi koefisien korelasi dimaksudkan untuk mengukur tingkat signifikansi keterkaitan antara variabel X dan variabel Y. Membandingkan $t_{\text {hitung }}$ dengan $t_{\text {tabei }}$ untuk $\alpha=$ 0,05 , uji satu pihak, dan derajat kebebasan $(\mathrm{dk})=\mathrm{n}-2$, dengan kaidah pengujian sebagai berikut: Jika $t_{\text {hitung }} \geq t_{\text {tabei, maka } H_{o} \text { ditolak artinya signifikan, dan Jika }} t_{\text {hitung }} \leq t_{\text {tabei }}$ maka $\mathrm{H}_{\mathrm{o}}$ diterima artinya tidak signifikan, Tingkat kesalahan dalam uji signifikan ini adalah $5 \%$ dengan derajat kebebasan $(d k)=n-2$.

\section{HASIL}

\subsection{Pengaruh gaya kepemimpinan transformasional kepala sekolah terhadap etos kerja guru dan staf}

Hasil penelitian menunjukkan bahwa hipotesis "Terdapat pengaruh yang positif dan signifikan dari kepemimpinan transformasional terhadap etos kerja". Hal ini dapat dilihat dari hasil pengolahan data yang menunjukkan adanya tingkat keterkaitan antara variabel $\mathrm{X}$ (kepemimpinan transformasional) dan variabel Y (etos kerja).

Tabel 3. Hasil korelasi

\begin{tabular}{rlrr}
\hline & & \multicolumn{2}{c}{$\mathrm{Y}$} \\
\hline \multirow{4}{*}{ X } & Pearson correlation & 1 & $.370^{* *}$ \\
& Sig. (2-tailed) & & .005 \\
& N & 56 & 56 \\
& Pearson correlation & .370 & 1 \\
Y & Sig. (2-tailed) & .005 & \\
& N & 56 & 56 \\
\hline
\end{tabular}


**. Correlation is significant at the 0.01 level (2-tailed)

Berdasarkan hasil perhitungan tersebut, dapat diketahui bahwa nilai korelasi pada variabel X (Gaya kepemimpinan transformasional kepala sekolah) dan variabel Y (Etos kerja guru dan staf) adalah sebesar 0,370. Untuk mengetahui tingkat hubungan antara kedua variabel tersebut, skor dikonsultasikan dengan koefisien korelasi pada nilai r. Maka koefisien korelasi dengan nilai 0,370 rendah, artinya tingkat korelasi antar variabel rendah. Hal ini dapat ditafsirkan bahwa hubungan antara gaya kepemimpinan transformasional kepala sekolah dengan etos kerja guru dan staf memiliki hubungan yang rendah.

Tabel 4. Hasil Koefisiensi

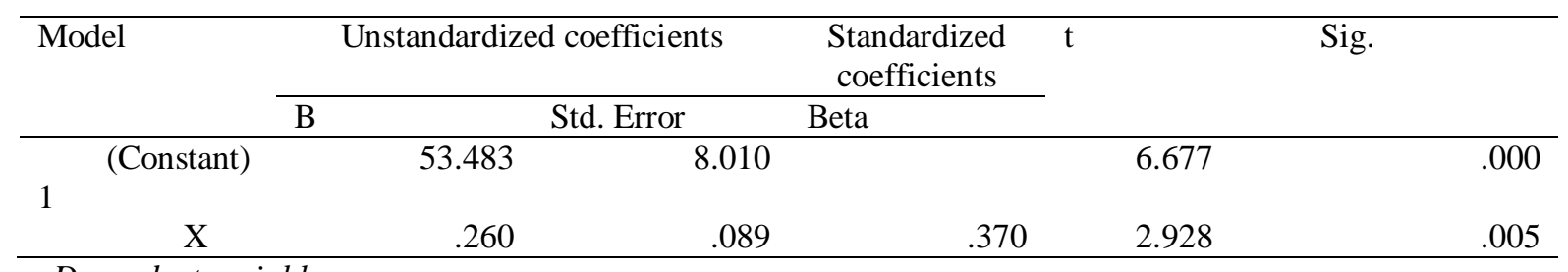

a. Dependent variable:

Berdasarkan hasil perhitungan tersebut, diperoleh hasil dari uji-t sebesar 2,928. Koefisien korelasi dianggap signifikan apabila $t$ hitung $>t$ tabel. Maka hasil yang diperoleh dari harga $t$ hitung adalah 2,928, sedangkan harga t tabel dengan $(\mathrm{dk}=\mathrm{n}-2)$ maka t tabel adalah 1,70562. Disimpulkan bahwa terdapat hubungan yang signifikan dan positif antara variabel X (Gaya kepemimpinan transformasional kepala sekolah) dan variabel Y (Etos kerja guru dan staf). Dari analisis regresi di atas, maka dapat diketahui bahwa nilai konstan (constant) sebesar 53,483 dan nilai beta sebesar 0,260 serta t hitung sebesar 2,928 dan tingkat signifikansi 0,005. Dari tabel koefisien diatas maka diperoleh persamaan regresi sederhana $\hat{Y}=53,483+0,260 \mathrm{X}$ yang artinya bahwa nilai regresi 0,260 menyatakan bahwa setiap penambahan satu poin gaya kepemimpinan transformasional kepala sekolah sebesar 0,260. Hal tersebut menyatakan bahwa prediksi yang searah/linier. Keterangan kenaikan atau penurunan variabel bebas (X) akan mengakibatkan kenaikan atau penurunan variabel terikat $(Y)$ dengan nilai sebesar 0,260. Dari hasil pengolahan data yang dikonsultasikan dengan tabel WMS dapat dibuat kesimpulan secara keseluruhan bahwa rata-rata skor untuk variabel X (gaya kepemimpinan transformasional kepala sekolah) adalah 2,86 yang menunjukan bahwa gaya kepemimpinan transformasional kepala sekolah termasuk dalam kategori baik. Hasil pengolahan data yang dikonsultasikan dengan tabel WMS maka dapat dibuat kesimpulan secara keseluruhan bahwa rata-rata skor untuk variabel Y (etos kerja guru dan staf) adalah 3,25 yang menunjukkan bahwa etos kerja guru dan staf termasuk dalam kategori sangat baik. 


\subsection{Kepemimpinan transformasional kepala sekolah}

Pada tabel 5 di bawah ini disajikan tentang hasil kepemimpinan transformasional kepala sekolah

Tabel 5. Kepemimpinan Transformasional Kepala Sekolah

\begin{tabular}{|c|c|c|c|c|c|c|c|c|c|c|c|c|}
\hline \multirow{3}{*}{ Indikator } & \multirow{3}{*}{$\begin{array}{l}\text { No. } \\
\text { Item }\end{array}$} & \multicolumn{8}{|c|}{ Alternatif jawaban } & \multirow{2}{*}{\multicolumn{2}{|c|}{ Jumlah }} & \multirow{3}{*}{$\begin{array}{c}\text { Rata-rata } \\
\text { f/x }\end{array}$} \\
\hline & & \multicolumn{2}{|c|}{4} & \multicolumn{2}{|c|}{3} & \multicolumn{2}{|c|}{2} & \multicolumn{2}{|c|}{1} & & & \\
\hline & & $\mathrm{f}$ & $\mathrm{x}$ & $\mathrm{f}$ & $\mathrm{x}$ & $\mathrm{f}$ & $\mathrm{x}$ & $\mathrm{f}$ & $\mathrm{x}$ & $\mathrm{f}$ & $\mathrm{x}$ & \\
\hline & 1 & 10 & 40 & 31 & 93 & 14 & 28 & 1 & 1 & 56 & 162 & 2,89 \\
\hline Idealized & 2 & 9 & 36 & 33 & 99 & 13 & 26 & 1 & 1 & 56 & 162 & 2,89 \\
\hline Influence & 3 & 9 & 36 & 31 & 93 & 14 & 28 & 2 & 2 & 56 & 159 & 2,83 \\
\hline Charismatic & 4 & 9 & 36 & 35 & 105 & 10 & 20 & 2 & 2 & 56 & 163 & 2,91 \\
\hline \multirow[t]{3}{*}{ (Karismatik) } & 5 & 9 & 36 & 39 & 117 & 8 & 16 & 0 & 0 & 56 & 169 & 3,01 \\
\hline & 6 & 5 & 20 & 33 & 99 & 16 & 32 & 2 & 2 & 56 & 153 & 2,73 \\
\hline & 7 & 11 & 44 & 42 & 126 & 3 & 6 & 0 & 0 & 56 & 176 & 3,14 \\
\hline Rata-Rata & \multicolumn{12}{|c|}{2,91} \\
\hline & 8 & 8 & 32 & 34 & 102 & 11 & 22 & 3 & 3 & 56 & 159 & 2,83 \\
\hline Inspirational & 9 & 12 & 48 & 31 & 93 & 12 & 24 & 1 & 1 & 56 & 166 & 2,96 \\
\hline Motivation & 10 & 12 & 48 & 27 & 81 & 16 & 32 & 1 & 1 & 56 & 162 & 2,89 \\
\hline (Motivation & 11 & 11 & 44 & 33 & 99 & 11 & 22 & 1 & 1 & 56 & 166 & 2,96 \\
\hline \multirow[t]{3}{*}{ Inspirasional) } & 12 & 10 & 40 & 26 & 78 & 19 & 38 & 1 & 1 & 56 & 157 & 2,80 \\
\hline & 13 & 12 & 48 & 36 & 108 & 8 & 16 & 0 & 0 & 56 & 172 & 3,07 \\
\hline & 14 & 12 & 48 & 28 & 84 & 15 & 30 & 1 & 1 & 56 & 163 & 2,91 \\
\hline Rata-Rata & \multicolumn{12}{|c|}{2,91} \\
\hline & 15 & 9 & 36 & 29 & 87 & 16 & 32 & 2 & 2 & 56 & 157 & 2,80 \\
\hline Intellectual & 16 & 12 & 48 & 35 & 105 & 7 & 14 & 2 & 2 & 56 & 169 & 3,01 \\
\hline Stimulation & 17 & 7 & 28 & 30 & 90 & 17 & 34 & 2 & 2 & 56 & 154 & 2,75 \\
\hline (Stimulasi & 18 & 8 & 32 & 35 & 105 & 12 & 24 & 1 & 1 & 56 & 162 & 2,89 \\
\hline \multirow[t]{3}{*}{ Intelektual) } & 19 & 9 & 36 & 32 & 96 & 14 & 28 & 1 & 1 & 56 & 161 & 2,87 \\
\hline & 20 & 13 & 52 & 35 & 105 & 8 & 16 & 0 & 0 & 56 & 173 & 3,08 \\
\hline & 21 & 13 & 52 & 32 & 96 & 11 & 22 & 0 & 0 & 56 & 170 & 3,03 \\
\hline Rata-Rata & \multicolumn{12}{|c|}{2,91} \\
\hline & 22 & 7 & 28 & 33 & 99 & 14 & 28 & 2 & 2 & 56 & 157 & 2,80 \\
\hline Individual & 23 & 4 & 16 & 29 & 87 & 20 & 40 & 3 & 3 & 56 & 146 & 2,60 \\
\hline Consideration & 24 & 5 & 20 & 35 & 105 & 13 & 26 & 3 & 3 & 56 & 154 & 2,75 \\
\hline (Perhatian & 25 & 6 & 24 & 34 & 102 & 13 & 26 & 3 & 3 & 56 & 155 & 2,76 \\
\hline terhadap & 26 & 6 & 24 & 32 & 96 & 10 & 20 & 8 & 8 & 56 & 148 & 2,64 \\
\hline \multirow[t]{2}{*}{ Individu) } & 27 & 4 & 16 & 35 & 105 & 16 & 32 & 1 & 1 & 56 & 154 & 2,75 \\
\hline & 28 & 8 & 32 & 31 & 93 & 16 & 32 & 1 & 1 & 56 & 158 & 2,82 \\
\hline Rata-Rata & \multicolumn{12}{|c|}{2,73} \\
\hline & & & & & Rat & aria & $X:$ & & & & & \\
\hline
\end{tabular}

Dari hasil pengolahan data seperti tampak pada tabel 3, maka dapat disimpulkan secara keseluruhan bahwa rata-rata skor untuk variabel X (Kepemimpinan Transformasional Kepala Sekolah) adalah 2,86 yang menunjukan bahwa kepemimpinan transformasional kepala sekolah termasuk dalam kategori baik. Temuan penelitian ini menunjukan bahwa gambaran kepemimpinan transformasional kepala sekolah berdasarkan perhitungan weight means score (WMS) diperoleh skor rata-rata sebesar 2,86. Skor tersebut kemudian dikonsultasikan dengan tabel konsultasi hasil perhitungan WMS, maka skor tersebut berada pada kategori baik. Hal ini memberikan gambaran bahwa, secara umum peran kepemimpinan transformasional kepala 
sekolah di Sekolah Menengah Pertama Negeri 12 Bandung dapat dikatakan baik. Berdasarkan hasil penilaian guru dan staf (responden) dapat diartikan kepala sekolah telah mampu menjalankan dan menerapkan peran kepemimpinan transformasional di Sekolah Menengah Pertama Negeri 12 Bandung dengan menekankan kepada indikator menjadi sosok yang karismatik, dapat memberikan motivasi inspirasional, stimulasi intelektual dan juga perhatian terhadap individu. Hal ini diperjelas dengan gambaran uji kecenderungan dari keempat sub variabel yang menjadi karakteristik kepemimpinan transformasional kepala sekolah yang ada didalam penelitian ini. Untuk sub variabel yang pertama, yaitu idealized influence charismatic memperoleh skor rata-rata sebesar 2,91 dengan kategori baik. Kemudian inspirational motivation memperoleh skor rata-rata sebesar 2,91 dengan kategori baik. Selanjutnya intellectual stimulation memperoleh skor rata-rata sebesar 2,91 dengan kategori baik. Terakhir, individual consideration memperoleh skor rata-rata sebesar 2,73 dengan kategori baik.

\subsection{Etos Kerja Guru dan Staf di Sekolah}

Pada tabel 5 disajikan hasil jawaban mengenai etos kerja guru dan staf:

Tabel 5. Etos Kerja Guru dan Staf

\begin{tabular}{|c|c|c|c|c|c|c|c|c|c|c|c|c|}
\hline \multirow{3}{*}{ Indikator } & \multirow{3}{*}{$\begin{array}{l}\text { No. } \\
\text { Item }\end{array}$} & \multicolumn{8}{|c|}{ Alternatif jawaban } & \multirow{2}{*}{\multicolumn{2}{|c|}{ Jumlah }} & \multirow{3}{*}{$\begin{array}{c}\text { Rata-rata } \\
\text { F/X }\end{array}$} \\
\hline & & \multicolumn{2}{|c|}{4} & \multicolumn{2}{|c|}{3} & \multicolumn{2}{|c|}{2} & \multicolumn{2}{|c|}{1} & & & \\
\hline & & $f$ & $\mathrm{x}$ & $\mathrm{f}$ & $\mathrm{x}$ & $\mathrm{f}$ & $\mathrm{x}$ & $\mathrm{f}$ & $\mathrm{x}$ & $\mathrm{f}$ & $\mathrm{x}$ & \\
\hline & 1 & 45 & 180 & 11 & 33 & 0 & 0 & 0 & 0 & 56 & 213 & 3,80 \\
\hline Tanggung jawab & 2 & 31 & 124 & 24 & 72 & 1 & 2 & 0 & 0 & 56 & 198 & 3,53 \\
\hline dalam melakukan & 3 & 35 & 140 & 21 & 63 & 0 & 0 & 0 & 0 & 56 & 203 & 3,62 \\
\hline \multirow[t]{4}{*}{ pekerjaan } & 4 & 30 & 120 & 26 & 78 & 0 & 0 & 0 & 0 & 56 & 198 & 3,53 \\
\hline & 5 & 26 & 104 & 30 & 90 & 0 & 0 & 0 & 0 & 56 & 194 & 3,46 \\
\hline & 6 & 23 & 92 & 32 & 96 & 1 & 2 & 0 & 0 & 56 & 190 & 3,39 \\
\hline & 7 & 26 & 104 & 30 & 90 & 0 & 0 & 0 & 0 & 56 & 194 & 3,46 \\
\hline Rata-Rata & \multicolumn{12}{|c|}{3,54} \\
\hline \multirow{7}{*}{$\begin{array}{l}\text { Prestasi yang } \\
\text { dicapai }\end{array}$} & 8 & 17 & 68 & 35 & 105 & 4 & 8 & 0 & 0 & 56 & 181 & 3,23 \\
\hline & 9 & 21 & 84 & 25 & 75 & 9 & 18 & 1 & 1 & 56 & 178 & 3,17 \\
\hline & 10 & 18 & 72 & 25 & 75 & 8 & 16 & 5 & 5 & 56 & 168 & 3 \\
\hline & 11 & 23 & 92 & 28 & 84 & 5 & 10 & 0 & 0 & 56 & 186 & 3,32 \\
\hline & 12 & 25 & 100 & 31 & 93 & 0 & 0 & 0 & 0 & 56 & 193 & 3,44 \\
\hline & 13 & 16 & 64 & 32 & 96 & 7 & 14 & 1 & 1 & 56 & 175 & 3,12 \\
\hline & 14 & 21 & 84 & 28 & 84 & 7 & 14 & 0 & 0 & 56 & 182 & 3,25 \\
\hline Rata-Rata & \multicolumn{12}{|c|}{3,21} \\
\hline \multirow{6}{*}{$\begin{array}{l}\text { Pengembangan } \\
\text { diri }\end{array}$} & 15 & 19 & 76 & 33 & 99 & 3 & 6 & 1 & 1 & 56 & 182 & 3,25 \\
\hline & 16 & 24 & 96 & 31 & 93 & 1 & 2 & 0 & 0 & 56 & 191 & 3,41 \\
\hline & 17 & 15 & 60 & 34 & 102 & 7 & 14 & 0 & 0 & 56 & 176 & 3,14 \\
\hline & 18 & 20 & 80 & 35 & 105 & 1 & 2 & 0 & 0 & 56 & 187 & 3,33 \\
\hline & 19 & 19 & 76 & 27 & 81 & 9 & 18 & 1 & 1 & 56 & 176 & 3,14 \\
\hline & 20 & 12 & 48 & 28 & 84 & 16 & 32 & 0 & 0 & 56 & 164 & 2,92 \\
\hline Rata-Rata & \multicolumn{12}{|c|}{3,19} \\
\hline \multirow{5}{*}{$\begin{array}{l}\text { Kemandirian } \\
\text { dalam bertindak }\end{array}$} & 21 & 17 & 68 & 24 & 72 & 10 & 20 & 5 & 5 & 56 & 165 & 2,94 \\
\hline & 22 & 19 & 76 & 32 & 96 & 5 & 10 & 0 & 0 & 56 & 182 & 3,25 \\
\hline & 23 & 18 & 72 & 34 & 102 & 4 & 8 & 0 & 0 & 56 & 182 & 3,25 \\
\hline & 24 & 19 & 76 & 35 & 105 & 2 & 4 & 0 & 0 & 56 & 185 & 3,3 \\
\hline & 25 & 19 & 76 & 30 & 90 & 7 & 14 & 0 & 0 & 56 & 180 & 3,21 \\
\hline
\end{tabular}




\begin{tabular}{|c|c|c|c|c|c|c|c|c|c|c|c|c|}
\hline \multirow{5}{*}{ Indikator } & No. & \multicolumn{8}{|c|}{ Alternatif jawaban } & \multirow{2}{*}{\multicolumn{2}{|c|}{ Jumlah }} & \multirow{3}{*}{$\begin{array}{c}\text { Rata-rata } \\
\text { F/X }\end{array}$} \\
\hline & \multirow[t]{2}{*}{ Item } & \multicolumn{2}{|c|}{4} & \multicolumn{2}{|c|}{3} & \multicolumn{2}{|c|}{2} & \multicolumn{2}{|c|}{1} & & & \\
\hline & & $\mathrm{f}$ & $\mathrm{X}$ & $\mathrm{f}$ & $\mathrm{x}$ & $\mathrm{f}$ & $\mathrm{X}$ & $\mathrm{f}$ & $\mathrm{x}$ & $\mathrm{f}$ & $\mathrm{x}$ & \\
\hline & 26 & 7 & 28 & 24 & 72 & 24 & 48 & 1 & 1 & 56 & 149 & 2,66 \\
\hline & 27 & 14 & 56 & 34 & 102 & 7 & 14 & 1 & 1 & 56 & 173 & 3,08 \\
\hline Rata-Rata & \multicolumn{12}{|c|}{3,09} \\
\hline & & & To & Rat: & $\overline{\text { Rata }}$ & arial & $Y: 3$ & & & & & \\
\hline
\end{tabular}

Dari hasil pengolahan data pada tabel, maka dapat dibuat kesimpulan secara keseluruhan bahwa rata-rata skor untuk variabel $\mathrm{Y}$ (Etos Kerja Guru dan Staf) adalah 3,25 yang menunjukkan bahwa etos kerja guru dan staf termasuk dalam kategori sangat baik.

Temuan penelitian ini menunjukan bahwa gambaran etos kerja guru dan staf berdasarkan perhitungan weight means score (WMS) diperoleh skor rata-rata sebesar 3,25. Skor tersebut kemudian dikonsultasikan dengan tabel konsultasi hasil perhitungan WMS, maka skor tersebut berada pada kategori sangat baik. Hal ini memberikan gambaran bahwa, secara umum etos kerja guru dan staf di Sekolah Menengah Pertama Negeri 12 Bandung dapat dikatakan sangat baik. Berdasarkan hasil angket dapat diartikan guru dan staf telah mampu menjalankan tugasnya dengan menekankan kepada indikator yang dapat tanggung jawab dalam melakukan pekerjaan, prestasi yang dicapai, dapat mengembangkan diri dan juga kemandirian dalam bertindak.

Etos kerja guru dan staf terbagi menjadi empat indikator, yaitu: tanggung jawab dalam melakukan pekerjaan, prestasi yang dicapai, pengembangan diri, kemandirian dalam bertindak. Untuk memperjelaskan mengenai etos kerja guru dan staf di sekolah adalah sebagai berikut: 1) Tanggung jawab dalam melakukan pekerjaan, berdasarkan hasil perhitungan dengan menggunakan teknik Weight Means Score (WMS) dalam tanggung jawab dalam melakukan pekerjaan dengan nilai rata-rata sebesar 3,54. Hal ini menunjukkan bahwa tanggung jawab dalam melakukan pekerjaan termasuk dalam kategori sangat baik; 2) Prestasi yang dicapai, berdasarkan hasil perhitungan dengan menggunakan teknik Weight Means Score (WMS) dalam prestasi yang dicapai dengan nilai rata-rata sebesar 3,21. Hal ini menunjukkan bahwa prestasi yang dicapai termasuk dalam kategori sangat baik; 3) Pengembangan diri, berdasarkan hasil perhitungan dengan menggunakan teknik Weight Means Score (WMS) dalam pengembangan diri dengan nilai rata-rata sebesar 3,19 Hal ini menunjukkan bahwa pengembangan diri termasuk dalam kategori sangat baik; 4) Kemandirian dalam bertindak, berdasarkan hasil perhitungan dengan menggunakan teknik Weight Means Score (WMS) dalam kemandirian dalam bertindak dengan nilai rata-rata sebesar 3,09. Hal ini menunjukkan bahwa kemandirian dalam bertindak termasuk dalam kategori sangat baik. 


\section{PEMBAHASAN}

\subsection{Pengaruh gaya kepemimpinan transformasional kepala sekolah terhadap etos kerja guru dan staf.}

Pengaruh gaya kepemimpinan transformasional kepala sekolah terhadap etos kerja guru dan staf dari hasil penelitian menunjukkan bahwa hubungan antara gaya kepemimpinan transformasional kepala sekolah dengan etos kerja guru dan staf memiliki hubungan yang signifikan. Temuan ini sejalan dengan hasil penelitian Carudin (2011) yang menyatakan bahwa persentase etos kerja menyumbang relatif besar dikarenakan pengaruh dari gaya kepemimpinan transformasional. Hasil penelitian Pradana (2013) juga menyebutkan bahwa gaya kepemimpinan transformasional secara parsial memiliki pengaruh yang signifikan terhadap etos kerja karyawan. Hasil penelitian ini mendukung penelitian terdahulu yang dilakukan oleh Rolasmana (2013) dengan judul "Pengaruh Gaya Kepemimpinan, Efektivitas Pengambilan Keputusan, dan Pemberian Kompensasi Insentif terhadap Kinerja Karyawan Bagian Keuangan pada Swalayan di Tanjungpinang" dan mendapatkan kesimpulan bahwa gaya kepemimpinan berpengaruh signifikan terhadap etos kerja karyawan.

Luthans (2006) menyatakan bahwa kepemimpinan transformasional membawa keadaan menuju kinerja karyawan yang tinggi pada organisasi yang menghadapi tuntutan pembaharuan dan perubahan. Hasil penelitian tersebut didukung oleh penelitian terdahulu yang dilakukan oleh Bass dan Avolio (1993) yang menunjukkan pengaruh positif kepemimpinan terhadap kinerja karyawan. Pada penelitian ini sudah terlihat berdasarkan informasi yang didapatkan dari hasil analisis data bahwa memang gaya kepemimpinan kepala sekolah yang transformasional mempengaruhi secara signifikan terhadap etos kerja guru dan staf. Senada dengan penelitian yang dilakukan Solechah et al (2011) menerangkan bahwa kepemimpinan transformasional berpengaruh signifikan terhadap variabel kinerja. Rasyid (2013) dalam penelitiannya juga menerangkan bahwa terdapat hubungan yang positif dan signifikan pengaruh kepemimpinan transformasional terhadap kinerja karyawan.

\subsection{Kepemimpinan transformasional kepala sekolah di sekolah}

Temuan penelitian ini menunjukan bahwa gambaran kepemimpinan transformasional kepala sekolah dapat dikatakan baik. Berdasarkan hasil penilaian guru dan staf (responden) dapat diartikan kepala sekolah telah mampu menjalankan dan menerapkan peran kepemimpinan transformasional di SMP Negeri 12 Bandung dengan menekankan kepada indikator menjadi 
sosok yang kharismatik, dapat memberikan motivasi inspirasional, stimulasi intelektual dan juga perhatian terhadap individu.

Hal tersebut sejalan dengan pendapat bahwa kepemimpinan transformasional merupakan pemimpin yang kharismatik dan mempunyai peran sentral serta strategi dalam membawa organisasi mencapai tujuannya, mempunyai kemampuan untuk menyamakan visi masa depan dengan bawahannya, serta mempertinggi kebutuhan bawahan pada tingkat yang lebih tinggi dari pada apa yang mereka butuhkan. Selanjutnya, mampu bekerja dengan dan/atau melalui orang lain untuk mentransformasikan, secara optimal sumber daya organisasi dalam rangka mencapai tujuan yang bermakna sesuai dengan target capaian yang telah ditetapkan, dimana para pengikut merasa adanya kepercayaan, kekaguman, kesetiaan, dan hormat terhadap pemimpin, dan mereka termotivasi untuk melakukan lebih dari pada yang awalnya diharapkan mereka. Serta berfokus pada pencapaian perubahan nilai-nilai, kepercayaan, sikap, perilaku, emosional, dan kebutuhan bawahan menuju perubahan yang lebih baik di masa depan, menginspirasi para pengikutnya untuk menyampingkan kepentingan pribadi mereka demi kebaikan organisasi dan mampu memiliki pengaruh yang luar biasa pada diri para pengikutnya dan adanya keinginan untuk melebarkan batas dan memiliki kinerja melampaui status quo organisasi mencapai serangkaian sasaran organisasi yang sepenuhnya baru (Danim, 2004, Bastian dalam Yukl, 2010, Burn dalam Safaria, 2004, Robbins, 2010 dan O’Leary dalam Pradana, 2013).

Hal senada dikatakan Robbins (2010) bahwa gaya kepemimpinan transformasional mempunyai dimensi kharismatik, stimulus, intelektual, konsiderasi individual, serta motivasi inspirasional. Jika pemimpin berhasil mempengaruhi bawahan dengan visinya, menanamkan karismanya memotivasi dan menjadi inspirator, menstimulasi intelektual, kreativitas dan menghargai karyawannya maka dapat dipastikan karyawan akan bekerja dengan baik, sungguh-sungguh dan loyal pada perusahaan sehingga kinerjanya meningkat.

\subsection{Etos kerja guru dan staf di sekolah}

Etos kerja guru dan staf di SMP Negeri 2 ini tergolong baik, hal itu salah satu faktor pendukungnya karena gaya kepemimpinan kepala sekolah yang cendrung ke arah transformasional. Kepemimpinan transformasional kepala sekolah bermuara pada perwujudan sekolah yang bermutu. Kepala sekolah dapat mengembangkan kharismanya untuk tujuan memunculkan emosi yang kuat sehingga bisa mengidentifikasi personel sekolah dengan gaya kepemimpinannya sendiri. Kepala sekolah harus memunculkan keteladanan sebagai upaya untuk mengikat emosi pengikut agar bisa memahami apa yang harus dilakukan untuk mencapai 
tujuan sekolah. Senada dengan penelitian ini, Robbins (2008) mengatakan bahwa kepala sekolah dengan gaya transformasional harus dapat membimbing guru dan staf kepada tujuan sekolah dan juga karisma menjadi salah satu indikator kepemimpinan transformasional yaitu idealized influence charismatic yang akan berdampak pada etos kerja guru dan staf.

Pandangan di atas ternyata sesuai dengan hasil uji kecenderungan dari keempat sub variabel yang menjadi karakteristik etos kerja guru dan staf yang ada didalam penelitian ini. Sub variabel yang pertama, yaitu tanggung jawab dalam melakukan pekerjaan memperoleh kategori sangat baik. Kemudian prestasi yang dicapai dengan kategori sangat baik. Selanjutnya pengembangan diri dengan kategori sangat baik. Terakhir kemandirian dalam bertindak memperoleh kategori sangat baik. Hal ini menunjukan bahwa etos kerja guru dan staf di sekolah berada dalam kategori sangat baik. Etos kerja guru dan staf pun menjadi salah satu faktor keberhasilan sekolah. Hal ini menunjukkan bahwa guru dan staf berada pada kategori sangat baik di tiap indikator yakni tanggung jawab dalam melakukan pekerjaan, prestasi yang dicapai, pengembangan diri dan kemandirian dalam bertindak.

Dengan melihat hasil rata-rata dengan kategori sangat baik, hal ini menunjukkan kondisi yang positif dalam hal etos kerja guru dan staf. Namun perlu diperhatikan terhadap sub variabel kemandirian dalam bertindak dengan perolehan skor terendah. Maka perlu ditingkatkan lagi dalam hal bagaimana guru dan staf perlu mandiri dalam melakukan sebuah tindakan yang tentunya dalam pengawasan seorang kepala sekolah.

Hal ini sejalan dengan yang dikemukakan oleh Sinamo (2005) dan Anoraga (1992) bahwa etos tidak saja sebagai perilaku khas dari sebuah organisasi atau komunitas tetapi juga mencakup motivasi yang menggerakkan mereka, karakteristik utama, spirit dasar, pikiran dasar, kode etik, kode moral, kode perilaku, sikap-sikap, aspirasi-aspirasi, keyakinankeyakinan, prinsip-prinsip, dan standar-standar, merupakan suatu pandangan dan sikap suatu bangsa atau umat terhadap kerja. Bila individu-individu dalam komunitas memandang kerja sebagai suatu hal yang luhur bagi eksistensi manusia, maka etos kerjanya akan cenderung tinggi. Sebaliknya sikap dan pandangan terhadap kerja sebagai sesuatu yang bernilai rendah bagi kehidupan, maka etos kerja dengan sendirinya akan rendah.

Etos kerja merupakan seperangkat perilaku positif yang berakar pada keyakinan fundamental yang disertai komitmen total pada paradigma kerja yang integral. Apabila suatu sekolah menganut paradigma kerja, mempercayai, dan berkomitmen pada paradigma kerja tersebut, semua itu akan melahirkan sikap dan perilaku kerja yang khas. Itulah yang akan menjadi etos kerja dan budaya, memandang bahwa etos kerja merupakan fondasi dari sukses yang sejati dan otentik (Sinamo, 2005). Penelitian Ng \& Heldman (2016), menegaskan bahwa 
kepemimpinan transformasional telah terbukti mempengaruhi kinerja karyawan. Temuan tersebut menunjukkan bahwa Kepemimpinan transformasional terkait dengan variabel yang mewakili mekanisme tugas kinerja. Ini artinya kepemimpinan yang bersifat transformasional akan menghasilkan dan menciptakan etos kerja yang baik.

\section{SIMPULAN}

Hipotesis yang diajukan dalam penelitian yaitu pengaruh kepemimpinan transformasional kepala sekolah terhadap etos kerja guru dan staf di sekolah dapat diterima dan terdapat pengaruh yang signifikan antara variabel kepemimpinan transformasional kepala sekolah dengan variabel etos kerja guru dan staf di Sekolah Menengah Pertama Negeri 12 Bandung. Selanjutnya berdasarkan hasil perhitungan koefisien korelasi terdapat pengaruh yang cukup kuat, begitu pula dengan hasil perhitungan koefisien determinasi menunjukkan bahwa adanya pengaruh kepemimpinan transformasional kepala sekolah dengan etos kerja guru dan staf di sekolah menunjukkan arah positif dan linear. Adanya pengaruh yang relatif signifikan antara kepemimpinan transformasional kepala sekolah terhadap etos kerja guru dan staf. Hal ini menunjukan bahwa jika kepemimpinan transformasional kepala sekolah tidak optimal dilakukan maka akan berimplikasi kepala etos kerja guru dan staf yang kurang baik, sehingga akan berdampak kepada kualitas manajemen sekolah.

\section{Acknowledgement}

Diucapkan terima kasih kepada Departemen Administrasi Pendidikan UPI yang telah memfasilitasi penelitian ini dan kepada Kepala Sekolah SMPN 12 Bandung, yang telah banyak memberikan kontribusi dalam kegiatan penelitian ini.

\section{DAFTAR PUSTAKA}

Anoraga, P. (1992). Psikologi kerja. Jakarta: PT. Rineka Cipta.

Arikunto, S. (2006). Prosedur penelitian suatu pendekatan praktik. Jakarta: PT. Rineka Cipta. Carudin. (2011). Pengaruh kepemimpinan kepala sekolah dan iklim sekolah terhadap kinerja guru . Jurnal Administrasi Pendidikan.

Danim, S. (2004). Motivasi kepemimpinan dan efektivitas kelompok. Jakarta: PT. Rineka Cipta. Daryanto. (2005). Evaluasi pendidikan. Jakarta: Rineka Cipta.

Dubrin, A. (2005). Leadership. Jakarta: Prenada Media.

Ng, T. W., Lam, S. S., \& Feldman, D. C. (2016). Organizational citizenship behavior and counterproductive work behavior: Do males and females differ?. Journal of Vocational Behavior, 93, 11-32. 
Pradana, M. A., \& Bambang S. S. H. D. (2013). Pengaruh gaya kepemimpinan transformasional dan transaksional terhadap kinerja karyawan. Jurnal Administrasi Bisnis, Vol 4. No 1. Agustus 2013. Halaman 1-11.

Rees, E. (2001). Seven principles of transformational leadership: creating a synergy of energy. New York: Sage.

Robbins, S.P. (2008). Perilaku organisasi. Jakarta: PT Indeks

Robbins, S. Dan Timothy A, J. (2010). Perilaku organisasi. Jakarta: Salemba Empat.

Rolasmana. M. (2013). Pengaruh gaya kepemimpinan, efektivitas pengambilan keputusan, dan pemberian kompensasi insentif terhadap kinerja karyawan bagian keuangan pada swalayan di tanjungpinang. Jurnal. tanjung pinang: Universitas maritim

Safaria, T. (2004). Kepemimpinan. Yogyakarta: PT. Graha Ilmu.

Soetopo, H. W. S. (2010). Pengantar operasional administrasi pendidikan. Surabaya: Usaha nasional.

Sinamo, J. (2005). Etos kerja profesional. Jakarta: PT. Spirit Mahardika.

Sugiyono. (2013). Metode penelitian kuantitatif kualitatif dan R\&D. Bandung: Alfabeta.

Wahjosumidjo. (2002). Kepemimpinan dan motivasi. Jakarta: Ghalia Indonesia.

Yukl, G. (2010). Kepemimpinan dalam organisasi. Jakarta: PT.Indeks. 